\title{
The effectiveness of a complex microbial preparation when used in the vineyards of the Crimean Peninsula
}

\author{
$V$ Rzhevskaya $^{1, *}, E$ Semenova $^{1,2}, A$ Kuzmin $^{2}, N$ Lyamina $^{2}, I$ Tsokalo ${ }^{1}, N$ Gnilomedova ${ }^{2}$, and \\ $T$ Kokodey $^{2}$ \\ ${ }^{1}$ V.I. Vernadsky Crimean Federal University, 295007, Akademika Vernadskogo Avenue, 4, \\ Simferopol, Russia \\ ${ }^{2}$ Sevastopol State University, 33 Universitetskaya Street, 299053, Sevastopol, Russia
}

\begin{abstract}
A multicenter study of the application of the microbiological preparation $\mathrm{Embiko}^{\circledR}$ in vineyards with its introduction with drip irrigation in the Western foothill-seaside viticultural zone of Crimea was carried out. Granulometric analysis of the soil showed that in the experimental version with the use of Embiko ${ }^{\circledR}$, the specific content of its fine fractions increased by $5 \%$, i.e. the soil became looser. The introduction of Embico ${ }^{\circledR}$ in liquid form with drip irrigation gave an increase in yield by $1.3 \mathrm{~kg}$ per bush, while the sugar content of the berry juice improved by at least $8 \%$. An antistress effect on plants under the influence of treatment with a biological preparation was also revealed, which manifests itself in a significant functional improvement of the leaf apparatus and an increase in the growth rates of grape shoots. When using the biological preparation Embico ${ }^{\circledR}$, the profit or net income at the pilot site increased compared with the control option (without application) and, accordingly, the profitability of production increased by $79 \%$.
\end{abstract}

\section{Introduction}

The events of the first decades of the 21st century significantly influenced the state of nature and society, including the situation in agriculture. As a result, the main regional and global factors of an ecological, technogenic and geopolitical nature were formed, which determine the features of the modern development of the agrobiological approach in growing crops. According to the most conservative estimates, yield losses from harmful organisms and unfavorable, including stress factors, reach at least 35-50\%. The current situation has led to the formation of a consensus on the need to create environmentally sound systems of land use and cultivation of agricultural crops on the basis of abandoning technologies based on the chemicalization of agriculture [1-3].

Recently, in our country and abroad, a number of biological preparations have been developed based on various microorganisms with a complex of useful properties aimed at

\footnotetext{
* Corresponding author: viktoriyar45@mail.ru
} 
increasing soil fertility and productivity of cultivated plants, as well as the quality of the yield, reducing the application rates of mineral fertilizers and pesticides [4-6].

We have created a biological preparation Embico ${ }^{\circledR}$, which activates the development of agricultural plants, protects against phytopathogens and stress factors, and also maintains soil fertility [7-8].

Embico $^{\circledR}$ is a complex microbial preparation, which includes lactic acid bacteria, purple non-sulfur bacteria, saccharomycetes and products of their metabolism (lactic acid homofermentative streptobacteria of the genus Lactobacillus: L. plantarum 20 and L. casei 6, lactic acid homofermentative streptococci Lactococcus lactis 4/6, purple non-sulfur bacteria Rhodopseudomonas palustris 77 and Rh. sphaeroides 55, yeast Saccharomyces cerevisiae 75) [9]. Each of the listed groups of microorganisms has specific properties. Thus, lactic acid bacteria stimulate seed germination and plant growth processes in general, and also inhibit the development of phytopathogenic and intestinal opportunistic microorganisms due to antibiotic properties and a decrease in $\mathrm{pH}$ according to the secretion of organic acids [10]. Alcohols secreted by Saccharomycetes yeast enhance the antibiotic effect of metabolites of lactic acid bacteria [11]. Purple non-sulfur bacteria reduce the toxic effects of chloride salinity and drought, thereby providing an anti-stress effect on plants. In addition, the microorganisms that make up Embico® convert phosphate forms inaccessible to plants into soluble forms, fix atmospheric nitrogen, and thereby change the physicochemical structure of the soil, increasing the content of fine fractions in it [12].

The aim of the study is to assess the effectiveness of the new microbiological consortium in relation to the quantitative and qualitative indicators of the grape harvest in the conditions of the Western foothill- seaside viticulture zone of Crimea.

\section{Materials and methods}

Field trials were carried out on a 4-year-old grape culture of the Cardinal variety (stock Berlandieri x Riparia Kober 5 BB) PJSC AF "Chernomorets" (Uglovoe village, Bakhchisaraysky district) and Vostorg white variety (stock - Kober 5 BB) SE "Veselovskoe" (settlement Veseloe, Sudakskiy district) on soils representing low-humus southern chernozem (humus content is $1-2 \%$ ) with a high content of carbonates on gravellypebble deposits, from a depth of $80-150 \mathrm{~cm}$. The volumetric weight of the soil in the upper horizon is $1.29-1.33 \mathrm{~g} / \mathrm{cm}^{3}$, at a depth of $140 \mathrm{~cm}$ is $1.53-1.58$. The content of total nitrogen in the plantation layer is $1.12-1.13 \%$, the content of mobile potassium is $16.1-23.4 \mathrm{mg} / 100$ $\mathrm{g}$, the content of mobile phosphoric acid is $0.7-2.1 \mathrm{mg} / 100 \mathrm{~g}$ of soil. At the experimental site, all the necessary agrotechnical measures were carried out, according to the flow charts [13].

The tested biological preparation Embiko ${ }^{\circledR}$ with a titer of $10^{7}-10^{8} \mathrm{CFU}$ was introduced into the soil with drip irrigation (application rate of 5 1/ha and irrigation rate of $100 \mathrm{~m}^{3} / \mathrm{ha}$ ) 4 times during the growing season in the following terms: 1 spraying - "berry growth" - June 16; 2 spraying - "the beginning of ripening" - July 17; 3 spraying - "after harvest" August 30; 4 spraying - "leaf fall" - October 4 [14].

The areas of the control (without the introduction of a biological preparation) and experimental variants were 35 hectares. In each variant, counts and observations were carried out on 30 accounting grape bushes in three replicates (10 plants in each replication): agrobiological counts were carried out to assess the productive potential of grape plants (June 9), accounting to determine the qualitative and quantitative indicators of the harvest were carried out when harvesting grapes (August 16), soil sampling was carried out from the depth of the main active roots $(30-60 \mathrm{~cm})$ in three repetitions for each option for grain size analysis of the soil (October 24 after all 4 planned irrigations) [15-16]. 
Mathematical data processing was performed using the statistical program STATISTICA 10.0 at a significance level of $\mathrm{P}=0.95$ [17-19].

\section{Results and discussion}

The weather conditions of the growing season over the years of research were favorable for growing grapes (table 1).

Table 1. Meteorological indicators of the growing season of grapes in the conditions of Crimea.

\begin{tabular}{|c|c|c|c|c|}
\hline \multirow{2}{*}{ Indicators } & \multicolumn{2}{|c|}{ Average long-term } & \multicolumn{2}{c|}{$\begin{array}{c}\text { Average monthly over the years of } \\
\text { research }\end{array}$} \\
\cline { 2 - 5 } & $\begin{array}{c}\text { Air temperature } \\
\left({ }^{\circ} \mathrm{C}\right)\end{array}$ & $\begin{array}{c}\text { Precipitation } \\
(\mathrm{mm})\end{array}$ & $\begin{array}{c}\text { Air temperature } \\
\left({ }^{\circ} \mathrm{C}\right)\end{array}$ & $\begin{array}{c}\text { Precipitation } \\
(\mathrm{mm})\end{array}$ \\
\hline April & 10.3 & 31.0 & 7.7 & 57.3 \\
\hline May & 15.5 & 43.0 & 13.4 & 35.9 \\
\hline June & 18.7 & 54.0 & 18.7 & 64.9 \\
\hline Jule & 20.8 & 49.0 & 22 & 3.6 \\
\hline August & 20.2 & 42.0 & 20.3 & 5.4 \\
\hline September & 15.9 & 40.0 & 17 & 24 \\
\hline
\end{tabular}

The growing season differed from the average long-term indicators in the cooler and wetter spring, as well as the hot and dry second half of the summer period. The weather conditions led to a delay in the growing season and the beginning of harvest. Such conditions did not affect the quality and quantity of the harvest; the harvesting took place in a short time.

The potential productivity of vine plantations of the experimental site (table 2) was the same for all variants of the experiment (deviations are insignificant at the $95 \%$ level of probability), that is, the experiments were carried out on the same agronomic background.

Table 2. Potential productivity of grape plants of Cardinal variety.

\begin{tabular}{|c|c|c|c|}
\hline Option & Control & $\begin{array}{c}\text { Biological } \\
\text { preparation } \\
\text { Embiko }^{\circledR}\end{array}$ & $\begin{array}{c}\text { Least significant } \\
\text { difference at 5\% } \\
\text { significance level }\end{array}$ \\
\hline Eyes (pcs/bush) & 9.1 & 11.6 & 2.6 \\
\hline Normally developed shoots(pcs/bush) & 9.1 & 9.3 & 2.8 \\
\hline Fruit-bearing shoots (pcs/bush) & 7.1 & 7.3 & 2.8 \\
\hline Inflorescences (pcs/bush) & 12.6 & 14.6 & 2.5 \\
\hline Fruiting rate $\mathrm{R}_{1}$ & 1.4 & 2.0 & 0.2 \\
\hline Fertility rate $\mathrm{R}_{2}$ & 1.8 & 2.0 & 0.2 \\
\hline
\end{tabular}

One of the tasks of the research included carrying out a granulometric analysis of the soil at the experimental site, since the microorganisms included in the preparation are supposed to improve the nutrient regime of the soil and its physicochemical properties. The analysis data showed that in the experimental variant the specific content of fine fractions was higher than in the control and amounted to $18 \%$ versus $13 \%$ (table 3 ). The ratio of soil macrostructure to microstructure in the variant with the use of Embico ${ }^{\circledR}$ was 4.5 ; in control variant was 6.4. The numerical indicators of the ratio of the two main soil structures show that in the experimental variant the soil has become looser. The soils of the site in terms of their mechanical composition are classified as medium and heavy loamy, in this regard, an 
increase in fine fractions (microstructure) allows to improve the physicochemical properties of the soil, while improving the gas and water exchange of grape plants.

Table 3. Mechanical composition of the soil of PJSC "Chernomorets"*.

\begin{tabular}{|c|c|c|c|c|}
\hline \multicolumn{2}{|c|}{ Option } & Control & $\begin{array}{c}\text { Biological preparation } \\
\text { Embiko }^{\circledR}\end{array}$ & $\begin{array}{c}\text { Least significant } \\
\text { difference at 5\% } \\
\text { significance level }\end{array}$ \\
\hline \multirow{2}{*}{ Soil macrostructure } & $\mathrm{g}$ & 867 & 819 & 15.3 \\
\cline { 2 - 5 } & $\%$ & 87 & 82 & - \\
\hline \multirow{2}{*}{ Soil microstructure } & $\mathrm{g}$ & 133 & 13 & - \\
\cline { 2 - 5 } & $\%$ & 181 & 18 & - \\
\hline $\begin{array}{c}\text { The ratio of macro- and } \\
\text { microstructure of the soil }\end{array}$ & 6.4 & 4.5 & *Average weight of a soil sample is 1 kg. \\
\hline \multicolumn{7}{|c|}{} \\
\hline
\end{tabular}

When harvesting, one of the important counts was carried out to determine the qualitative and quantitative indicators of the yield, which showed that in the variant with the use of Embiko ${ }^{\circledR}$, the average mass of the bunch was more by $50.7 \mathrm{~g}$, and, in general, the yield from the bush was higher on $1.3 \mathrm{~kg}$ (table 4). In terms of 1 hectare, the yield was 4.00 $\mathrm{t} / \mathrm{ha}$ on the variant with the use of Embiko ${ }^{\circledR}$, and $2.92 \mathrm{t} / \mathrm{ha}$ on the control one. This is due to the fact that the vineyard was beginning to bear fruit, therefore, the yield as a whole for the plot is not high because of the control of the load, but the weight of the average bunch mass was typical for this variety.

Table 4. Qualitative and quantitative indicators of the grape harvest of Cardinal variety, PJSC "Chernomorets".

\begin{tabular}{|c|c|c|c|}
\hline Option & Control & $\begin{array}{c}\text { Biological } \\
\text { preparation } \\
\text { Embiko }^{\circledR}\end{array}$ & $\begin{array}{c}\text { Least significant } \\
\text { difference at 5\% } \\
\text { significance level }\end{array}$ \\
\hline Number of bunches (pcs/bush) & 12.3 & 14.2 & 2.5 \\
\hline Average bunch weight (g) & 285.4 & 336.1 & 9.6 \\
\hline Yield (kg/bush) & 3.5 & 4.8 & 0.4 \\
\hline $\begin{array}{c}\text { Mass concentration of sugars (g/100 } \\
\mathrm{cm}^{3} \text { ) }\end{array}$ & 17.0 & 18.5 & 0.3 \\
\hline
\end{tabular}

The quality indicator of grapes - the mass concentration of sugars - was better in the variant with the use of Embiko ${ }^{\circledR}$ and amounted to $18.5 \mathrm{~g} / 100 \mathrm{~cm}^{3}$ against $17 \mathrm{~g} / 100 \mathrm{~cm}^{3}$ in the control (table 4).

The effect of treatment with a complex biological preparation on the yield and sugar content of grapes revealed by us was confirmed at the experimental site of the SE "Veselovskoe" (table 5).

Table 5. Qualitative and quantitative indicators of the grape harvest of the Vostorg white variety, SE "Veselovskoe".

\begin{tabular}{|c|c|c|}
\hline Option & Control & Biological preparation Embiko $^{\circledR}$ \\
\hline Area (ha) & 6.50 & 7.82 \\
\hline Gross collection (t) & 14.6 & 19.6 \\
\hline Productivity (t/ha) & 22.5 & 25.1 \\
\hline Sugar content (\%) & 20.5 & 21.1 \\
\hline
\end{tabular}


Calculation of economic indicators of grape production showed that the increase in yield when processing vineyards with a biological preparation compensated for the costs of its introduction (table 6).

Table 6. Some economic indicators of the grape production of Cardinal variety.

\begin{tabular}{|c|c|c|}
\hline Economic indicators & Control & Biological preparation Embiko \\
\hline Area (ha) & 35 & 35 \\
\hline Productivity (t/ha) & 2.9 & 4.0 \\
\hline Gross collection $(\mathrm{t})$ & 101.5 & 140.0 \\
\hline Profitability (\%) & 118 & 197 \\
\hline
\end{tabular}

Taking into account the cost of applying the microbiological preparation Embico ${ }^{\circledR}$ in liquid form, the profit or net income at the pilot site increased compared to the option without adding the preparation and, accordingly, the profitability of production increased by $79 \%$ (table 6 ).

To identify the possibility of reducing the impact of stress factors on plants, tests were carried out on the grape of Vostorg white variety, which was treated with a herbicide $(0.03 \%$ colloidal sulfur solution and $0.04 \% \mathrm{Bi}-58)$, damaged young shoots and part of the inflorescences (brown ends leaves, drip burns). After treating the vineyard with a microbiological preparation, after three days, the leaf apparatus of the plants acquired the color corresponding to the variety and the turgor of the leaves improved significantly. After 1 month, the shoots were $40 \pm 3 \mathrm{~cm}$ longer than the fired control ones.

In general, there were positive trends in reducing the negative impact of herbicides during their overdose: the quantitative and qualitative indicators of the shoots and leaf apparatus of the grape plant increased.

\section{Conclusions}

According to the results of a multicenter study of the application of the microbiological preparation Embiko ${ }^{\circledR}$ on grapes when applied with drip irrigation in the Western foothillseaside viticultural zone of Crimea, the following conclusions can be drawn.

1. Granulometric analysis of the soil showed that in the experimental version with the use of Embico $\AA$ in liquid form, the specific content of its fine fractions increased by $5 \%$, that is, the soil became looser.

2. Application of Embico ${ }^{\circledR}$ with drip irrigation gave an increase in yield by $1.3 \mathrm{~kg}$ per bush, while the sugar content of the berry juice improved by at least $8 \%$.

3. When using a new biological preparation, the profit or net income at the experimental site increased compared to the control option (without introduction) and, accordingly, the profitability of production increased by $79 \%$.

4. The anti-stress effect of the biological preparation was revealed, which manifests itself in a significant improvement in the leaf apparatus of plants and an increase in the growth rates of grape shoots.

\section{References}

1. Suleimenova N, Zharaspayeva S and Kurmanbaeva M 2016 Environmental aspects and economic assessment chemicalization agriculture under agro-ecosystems Research J. of Pharmaceutical, Biological and Chemical Sciences 7(5) 1175-84

2. Semenda D and Semenda O 2018 Assessment of ecological and economic efficiency of 
agricultural lands preservation Environmental Economics 9(1) 47-56

3. Giodowska M and Wozniak M 2019 Changes in Soil Microbial Activity and Community Composition as a Result of Selected Agricultural Practices Agricultural Sciences $10330-51$

4. Itelima J U, Bang W J, Sila M D, Onyimba I A and Egbere O J 2018 A review: Biofertilizer - A key player in enhancing soil fertility and crop productivity Microbiol Biotechnol Rep 2(1) 22-8

5. Javaid A 2010 Beneficial Microorganisms for Sustainable Agriculture Genetic Eng., Biofertilisation, Soil Quality and Organic Farming 347-69

6. Azizbekyan R 2019 Biological Preparations for the Protection of Agricultural Plants (Review) Applied Biochemistry and Microbiology 55(8) 816-23

7. Rjevskaya V S and Omelchenko A V 2015 Influence of the microbiological preparation Embiko $^{\circledR}$ on the infection of winter wheat seeds with phytopathogenic fungi Young scientist 18 (98) 33-6

8. Rjevskaya V S, Otirina I P, Buligin S V and Teplitskaya L M 2014 Influence of the microbial preparation Embiko ${ }^{\circledR}$ on the growth, fruit formation of cucumbers and biological activity of the soil Scientific notes of V I Vernadsky Taurida National University Series "Biology, chemistry" 27 (66) 124-37

9. Rjevskaya V S, Otirina I P and Teplitskaya L M 2014 Influence of lactic acid bacteria on the growth parameters of cucumber plants Cucumis sativus L. at the initial stages of development Scientific notes of V I Vernadsky Taurida National University Series "Biology, chemistry" 27 (66) 145-60

10. Filimonov V M, Merlich A G and Lymanska N V 2016 Injection of the consortium of Lactobacillus plantarum strains on the growth characteristics of steams in the Lactica sativa L. lettuce. Bulletin of the ONU. Biology V. 211 (38) 143-52

11. Boyarineva I V, Engineering C S, Khamagaeva I S and Dr. S Engineering, Prof. 2015 The study of the conditions for microflora symbiotic yeast cultivation for bakeries Bulletin of the East Siberian State University of Technology and Management 2 (53) 74-80

12. Tsygankov A A and Gogotov I N 1990 Obtaining biomass of purple non-sulfur bacteria Applied biochemistry and microbiology 26 819-24

13. Vorobeva T N, Petrov V S, Prach A V and Belkov A S C 2018 Biological methods of soil maintenance in vineyards: methodological recommendations (Krasnodar: FGBNU SKFNTSVV) p 42

14. Serpuchovitina K A 2010 Methodological and analytical support for organizing and conducting research on the technology of grape production (Krasnodar: GNU NKZNIISiV) p 182

15. Ivancenko N I, Beibulatov M R, Antipov V P, Sogonan R Y A, Amirdzhanov A G et al 2001 Methodological recomnendations for agrotechnical research in viticulture of Ukraine (Yalta: IViV "Magarach") p 264

16. Terpelec V I and Slusarev V N 2016 Agrophysical and agrochemical methods of soil research study guide (Krasnodar: KubSAU) p 65

17. Borovikov V 2003 STATISTICA. Iskusstvo analiza dannikh na kompyutere: dlya professionalov STATISTICA. The art of data analysis using computer: for professionals ( $\mathrm{SPb}$ : Piter) p 688

18. Kozlov G, Pushkarev M 2019 E3S Web of Conferences 13501058 doi:10.1051/e3sconf/201913501058 
19. Yagmurov E R, et al 2017 Journal of Hygienic Engineering and Design 20 60-69 